\title{
Icariin induces apoptosis in mouse MLTC-10 Leydig tumor cells through activation of the mitochondrial pathway and down-regulation of the expression of piwil4
}

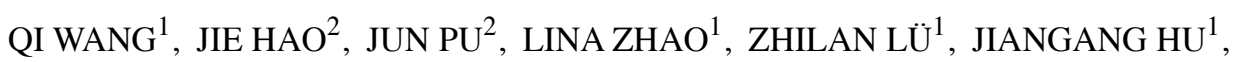 \\ QIUBO YU ${ }^{1}$, YINGXIONG WANG ${ }^{1}$, YI XIE ${ }^{1}$ and GANG LI ${ }^{1}$ \\ ${ }^{1}$ School of Public Health, ${ }^{2}$ The First Affiliated Hospital, Chongqing Medical University, Chongqing 400016, P.R. China
}

Received March 23, 2011; Accepted May 20, 2011

DOI: $10.3892 /$ ijo.2011.1086

\begin{abstract}
The Leydig cell tumor, derived from interstitial cells, is a rare neoplasm. In most cases, Leydig cell tumors are benign, however, if the tumor is malignant, no effective treatments are currently available. In this study, we aimed to evaluate the effects of icariin on the growth of the mouse Leydig tumor cell line MLTC-1 and to examine its underlying mechanism. Icariin caused a dose-dependent decrease in the viability of MLTC-1 cells, which coincided with an increase in cell apoptosis through regulation of the expression of Bcl-2/Bax and cytochrome c, activation of caspase-9 and -3. Moreover, the pro-apoptotic effect of icariin on MLTC-1 cells is related to piwil4, since icariin induced a decrease in piwil4 protein expression and piwil4 silencing significantly enhanced the cytotoxic effects of icariin in MLTC-1 cells. These findings suggest a novel anticancer effect of icariin in Leydig cell tumor through activation of the mitochondrial pathway and down-regulation of the expression of piwil4.
\end{abstract}

\section{Introduction}

Testicular neoplasms include germ cell tumors and sex cord-stromal tumors. Germ cell tumors comprise $95 \%$ of all testicular neoplasms, while the remaining $5 \%$ of testicular tumors are sex cord-stromal tumors, which are derived from somatic cells, Sertoli and Leydig cells. The Leydig cell tumor is classified as an interstitial cell tumor, which are commonly benign; however, in adults, $\sim 10 \%$ of cases are malignant (1-4). The etiology of Leydig cell tumor in humans remains unknown. Currently, in most cases, the standard therapy for benign Leydig cell tumors is considered to be orchiectomy. Recently, by retrospectively analyzing the long-term follow-up

Correspondence to: Dr Gang Li or Dr Yi Xie, School of Public Health, Chongqing Medical University, Chongqing 400016, P.R. China E-mail: lg168sn@yahoo.com

E-mail: xieyi65@yahoo.com.cn

Key words: icariin, Leydig cell tumor, apoptosis, piwil4 of a series of patients with Leydig cell tumors electively treated with testis sparing surgery, Glannarin et al (5) demonstrated that testis sparing surgery with frozen section examination has an excellent long-term oncological outcome. Therefore, testis-sparing surgery may be chosen for treating benign Leydig cell tumors to maintain fertility, especially in boys and young men (5-9). If the tumor is malignant, orchiectomy with retroperitoneal lymph node dissection is recommended, since chemotherapy and radiation therapy show limited efficacy in the treatment of malignant Leydig cell tumors. Survival time of patients with this malignancy range from 2 months to 17 years, and the mean survival time is 2 years $(10,11)$. To improve the survival time of patients with malignant Leydig cell tumor, and to decrease the serious consequences, such as testicular dysfunction and infertility that is caused by the current treatment for benign Leydig cell tumors, alternative treatments need to be explored.

Icariin $\left(\mathrm{C}_{33} \mathrm{H}_{40} \mathrm{O}_{15}\right.$; molecular weight, 676.67), a flavonoid isolated from Herba Epimedii, is considered to be the main active component responsible for the actions of Herba Epimedii. Many studies have shown that it has a wide range of pharmacological and biological activities on endocrine, cardiovascular, genital, bronchial, urinary and immune systems (12-15). In vitro studies have demonstrated that icariin possesses antitumor activity $(16,17)$. Here we evaluated the effects of icariin on the growth of the mouse Leydig tumor cell line, MLTC-1 and examined its underlying mechanism.

\section{Materials and methods}

Materials. Icariin (purity $>98 \%$ ) was purchased from China's National Institute for the Control of Pharmaceutical and Biological Products (Beijing, China). RPMI-1640 and fetal bovine serum (FBS) were purchased from HyClone. Caspase-3, -8 and -9 detection kit, the Annexin $\mathrm{V}$ apoptosis detection kit, the protein extraction kit and the BeyoECL Plus Western blotting detection reagent were purchased from Beyotime Institute of Biotechnology (Jiangsu, China). The BLOCK-iT ${ }^{\mathrm{TM}}$ HiPerform $^{\mathrm{TM}}$ Lentiviral Pol II miR RNAi Expression System with EmGFP and Lipofectamine 2000 were purchased from Invitrogen (USA). Anti-piwil4 (sc-67593), caspase-9 and -3 inhibitor (DEVD-CHO and z-LEHD-fmk) were purchased from 
Santa Cruz Biotechnology (Santa Cruz, CA, USA). Anti-Bcl-2, anti-Bax, anti-cytochrome $\mathrm{c}$ and anti- $\beta$-actin antibodies were purchased from Biosis (Beijing, China).

Cell culture. MLTC-1 cells were cultured in RPMI-1640 medium supplemented with $10 \%$ fetal bovine serum. All the cells were placed in an incubator, containing $95 \%$ air and 5\% $\mathrm{CO}_{2}$ at $37^{\circ} \mathrm{C}$, and the media were replaced every 2 days.

MTT assay. The activity of icariin on cell proliferation was assesed by the MTT assay. In brief, MLTC-1 cells were plated in 96-multiwell plates at a density of $5 \times 10^{4}$ cells/well. After adherent, icariin at indicated doses was added to the wells and incubated for 24 or $48 \mathrm{~h}$. At the indicated time after the treatment, the supernatant was removed and an MTT solution $(5 \mathrm{mg} /$ $\mathrm{ml}$ final concentration) was added. After $4 \mathrm{~h}$ incubation at $37^{\circ} \mathrm{C}$, the MTT solution was removed and formazan was dissolved in DMSO. MTT reduction in living cells was quantified at a $550 \mathrm{~nm}$ wavelength using a Sunrise Remote Microplate Reader (Grodig, Austria). Survival of control groups was defined as $100 \%$ surviving, and the number of living cells in the treated groups was expressed as a percentage of the control groups.

Flow cytometry for cell apoptosis analysis. MLTC-1 cells were treated with control medium or $50 \mu \mathrm{g} / \mathrm{ml}$ icariin for 24 or $48 \mathrm{~h}$, then the cells were harvested for the Annexin V assay using the Annexin V Apoptosis Detection Kit. Briefly, treated cells were centrifuged for $10 \mathrm{~min}$ to remove the media. Then the cells were rinsed with $1 \mathrm{X}$ binding buffer supplied by the manufacturer. The rinsed cells were resuspended in $200 \mu \mathrm{l}$ of binding buffer. Subsequently, $5 \mu \mathrm{l}$ of Annexin $\mathrm{V}$ and $10 \mu \mathrm{l}$ of PI were added and incubated at room temperature for $15 \mathrm{~min}$. Flow cytometric analysis was carried out using using a FACSVantage SE flow cytometer (Becton-Dickinson, USA).

Flow cytometric analysis of the cell cycle. To investigate the possible roles of icariin on the cell cycle, flow cytometric analysis was used. Cells $\left(1 \times 10^{6}\right)$ were trypsinized and centrifuged. The cell pellets were washed with PBS and fixed in $70 \%$ ethanol. Then MLTC-1 cells were centrifuged for $5 \mathrm{~min}$ and washed with $1 \mathrm{X}$ PBS, following a 30-min incubation with Hanks-buffered saline solution containing PI $(10 \mu \mathrm{g} / \mathrm{ml})$ and RNase $(100 \mu \mathrm{g} / \mathrm{ml})$ at room temperature. The cells were quantified on a FACSVantage SE flow cytometer (BectonDickinson).

Measurement of caspase $-3,-8$, and -9 activity. The activities of caspase- $3,-8$ and -9 were measured according to the manufacturer's instructions. In brief, MLTC-1 cells were removed from culture dishes, washed twice with PBS, and pelleted by centrifugation. Cell pellets were then treated for $10 \mathrm{~min}$ with iced lysis buffer. The suspensions were then centrifuged at $16000 \mathrm{x} \mathrm{g}$ for $15 \mathrm{~min}$, and the supernatants were collected. Subsequently, the caspase substrates (Ac-DEVD- $p$ NA for caspase-3, Ac-IETD- $p$ NA for caspase-8 and Ac-LEHD- $p$ NA for caspase-9) were added and the tubes were incubated at $37^{\circ} \mathrm{C}$ for $2 \mathrm{~h}$. During incubation, the caspases cleaved the substrates to form $p \mathrm{NA}$, and the release of $p \mathrm{NA}$ was determined using the absorbance at $405 \mathrm{~nm}$. The caspase- $3,-8$ and -9 activities were expressed as the percentage compared to control.
Western blot analysis. Briefly, for protein isolation, MLTC-1 cells were lysed with RIPA buffer. Insoluble material was removed by centrifugation at $12000 \mathrm{x}$ g for $10 \mathrm{~min}$ at $4^{\circ} \mathrm{C}$ and supernatants were collected. The protein concentration was determined by the BCA assay. Proteins were separated by SDS-PAGE on a $12 \%$ polyacrylamide and were transferred to a PVDF membrane, followed by antibody incubation. After washing three times, membranes were incubated with a secondary IgG antibody for $2 \mathrm{~h}$ and washed again. The antigen-antibody complex was detected using an Beyo-ECL kit following the manufacturer's protocol.

The effect of piwil4 on icariin-induced cell apoptosis. To evaluate the effect of piwil4 on icariin-induced cell apoptosis, the BLOCK-iT ${ }^{\mathrm{TM}}$ HiPerform $^{\mathrm{TM}}$ Lentiviral Pol II miR RNAi Expression System with EmGFP was employed to downregulate the expression of piwil4 in MLTC-1 cells. The sequence of oligonucleotides encoding the miRNA for piwil4 RNAi were as follows, top: 5'-TGCTGTAGTAATCCACA TATGTGACCGTTTTGGCCACTGACTGACGGTCAC ATGTGGATTACTA-3', bottom: 5'-CCTGTAGTAATCCAC ATGTGACCGTCAGTCAGTGGCCAAAACGGTCAC ATATGTGGATTACTAC-3'. Construction of the piwil4pcDNA $^{\mathrm{TM}}$ 6.2-GW/EmGFP miR vector and screening of the resistant colonies were performed according to manufacturer's procedure.

Subsequently, MLTC-1-NC cells (transfected with negative control vector) and MLTC-1-piwil4-RNAi (transfected with piwil4 miR RNAi vector) were treated without or with $50 \mu \mathrm{M}$ icariin for $24 \mathrm{~h}$, followed by the MTT test and cell apoptosis analysis as described above.

Statistical analysis. Data are expressed as the mean \pm SD. Statistical differences were evaluated by using ANOVA. The level for a statistically significant difference was set at $\mathrm{P}<0.05$.

\section{Results}

Effects of icariin on growth of MLTC-1 cells. To assess the anti-proliferative activity of icariin, MLTC-1 cells were treated with $12.5,25,50$ and $100 \mu \mathrm{g} / \mathrm{ml}$ of icariin for 24 or $48 \mathrm{~h}$. The MTT assay results demonstrated that $12.5 \mu \mathrm{g} / \mathrm{ml}$ icariin did not signficantly affect cell viability $(\mathrm{P}>0.05)$, while at concentrations above $12.5 \mu \mathrm{g} / \mathrm{ml}$, the cell viability of MLTC-1 cells was inhibited in a time- and dose-dependent manner. As shown in Fig. 1, 24-h treatment with 25, 50 and $100 \mu \mathrm{g} / \mathrm{ml}$ icariin significantly reduced cell viability to $82.20 \pm 3.89 \%$ $(\mathrm{P}<0.05), 67.79 \pm 5.29 \%(\mathrm{P}<0.01)$ and $55.93 \pm 6.72 \%(\mathrm{P}<0.01)$, respectively. Treatment with 25,50 and $100 \mu \mathrm{g} / \mathrm{ml}$ icariin after $48 \mathrm{~h}$ caused a reduction in cell viability to $65.93 \pm 8.72 \%$ $(\mathrm{P}<0.01), 48.90 \pm 5.30 \%(\mathrm{P}<0.01)$ and $30.77 \pm 6.24 \%(\mathrm{P}<0.01)$, respectively. The effective icariin concentration for $50 \%$ inhibition (EC50) of the MLTC-1 cell viability after $48 \mathrm{~h}$ was $50 \mu \mathrm{g} / \mathrm{ml}$, which was thus the concentration chosen for the subsequent experiments.

Icariin treatment $(50 \mu \mathrm{g} / \mathrm{ml})$ induces apoptosis in MLTC-1 cells. To quantitatively assess the effects of $50 \mu \mathrm{g} / \mathrm{ml}$ icariin on MLTC-1 cells, MLTC-1 cells were treated with medium (control) or with $50 \mu \mathrm{g} / \mathrm{ml}$ icariin for 24 or $48 \mathrm{~h}$. PI vs. Annexin V-FITC 


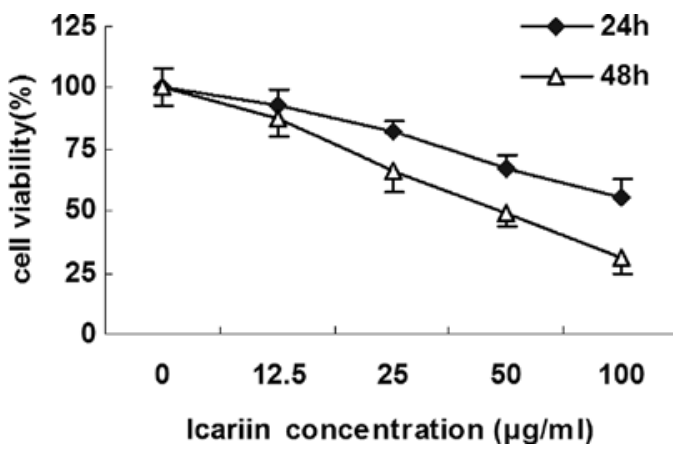

Figure 1. Inhibitory effects of icariin on MLTC-1 cell viability. MLTC-1 cells were treated with $12.5,25,50$ and $100 \mu \mathrm{g} / \mathrm{ml}$ icariin for 24 or $48 \mathrm{~h}$. At the end of the incubation period, the cell viability was estimated by MTT assay. The results are from three experiments and are presented as means \pm SD. fluorescence staining was then measured by flow cytometric analysis (Fig. 2). In the $24 \mathrm{~h}$ (Fig. 2A) and $48 \mathrm{~h}$ (Fig. 2C) vehicle-treated control group, $7.6 \pm 0.6 \%$ and $8.2 \pm 0.56 \%$ cells excluded PI and were positive for Annexin V-FITC binding, which represent the apoptotic cells. After exposure to $50 \mu \mathrm{g} /$ $\mathrm{ml}$ icariin for $24 \mathrm{~h}$ (Fig. 2B) and $48 \mathrm{~h}$ (Fig. 2D), the percentage of apoptosis increased to $17.1 \pm 1.5 \%(\mathrm{P}<0.01)$ and $24.7 \pm 1.6 \%$ $(\mathrm{P}<0.01)$, respectively.

Icariin affects the cell cycle progression of MLTC-1 cells. We determined the cell cycle phases in the cells with or without $50 \mu \mathrm{g} / \mathrm{ml}$ icariin treatment for 24 or $48 \mathrm{~h}$ by flow cytometric analysis (Fig. 3). The percentage of cells in the $\mathrm{G}_{1}$ and $\mathrm{G}_{2}$ phase after 24 or $48 \mathrm{~h}$ of icariin treatment was similar to that of the control groups $(\mathrm{P}>0.05)$. However, compared with
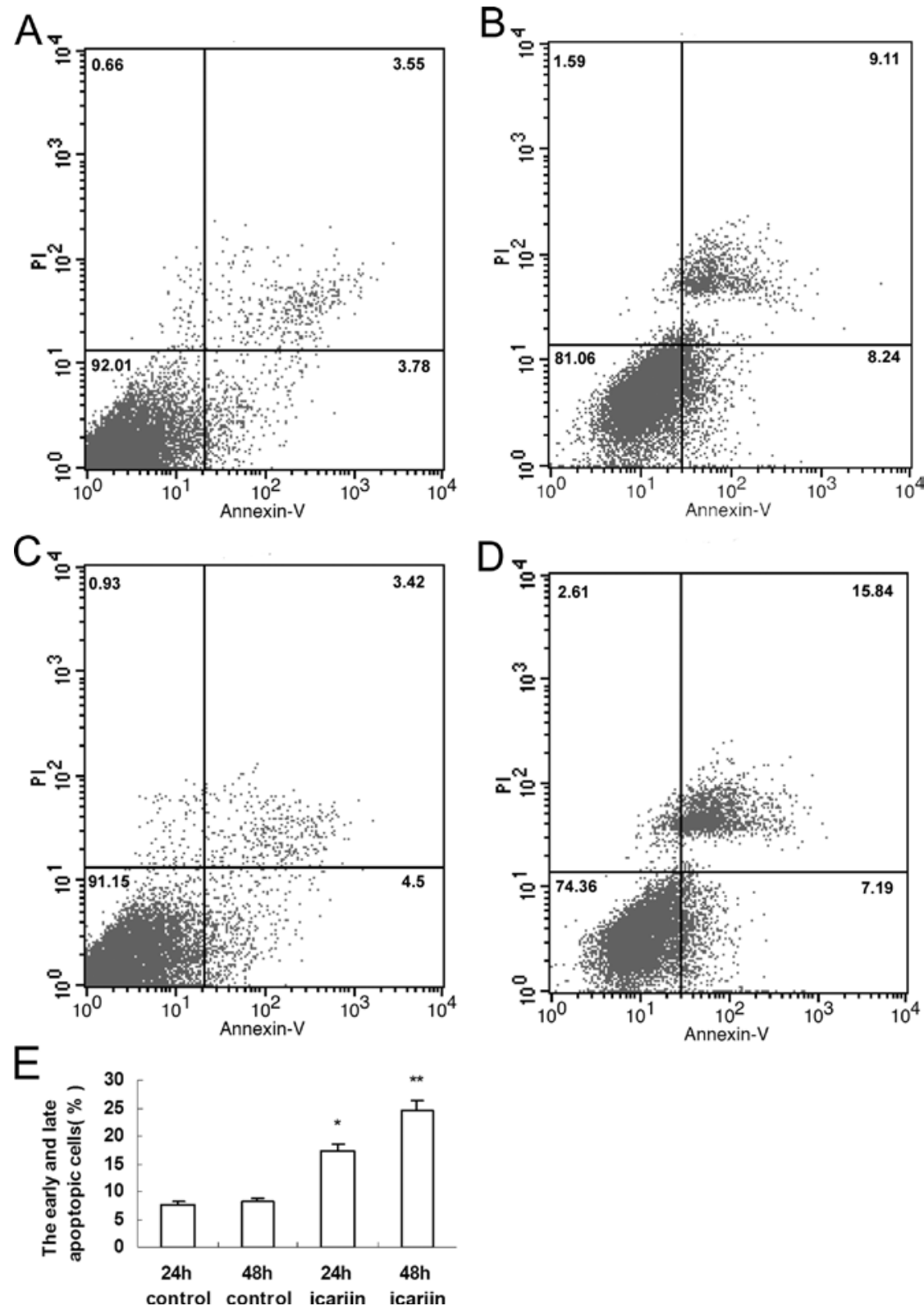

Figure 2. Treatment of MLTC-1 Leydig cells with $50 \mu \mathrm{g} / \mathrm{ml}$ icariin triggered apoptosis detected by the Annexin V/PI double-staining assay. The figures show representative flow cytometric histograms of cells treated with different experimental conditions. (A) The $24 \mathrm{~h}$ control group; (B) cells exposed to $50 \mu \mathrm{g} / \mathrm{ml}$ icariin for $24 \mathrm{~h}$; (C) the $48 \mathrm{~h}$ control group; (D) cells exposed to $50 \mu \mathrm{g} / \mathrm{ml}$ icariin for $48 \mathrm{~h}$. (E) The percentage of apoptotic cells for each treatment group. Values are the means $\pm \mathrm{SD}(\mathrm{n}=3)$. ${ }^{*} \mathrm{P}<0.01$, compared to the $24 \mathrm{~h}$ control group; ${ }^{* *} \mathrm{P}<0.01$, compared to the $48 \mathrm{~h}$ control group. 

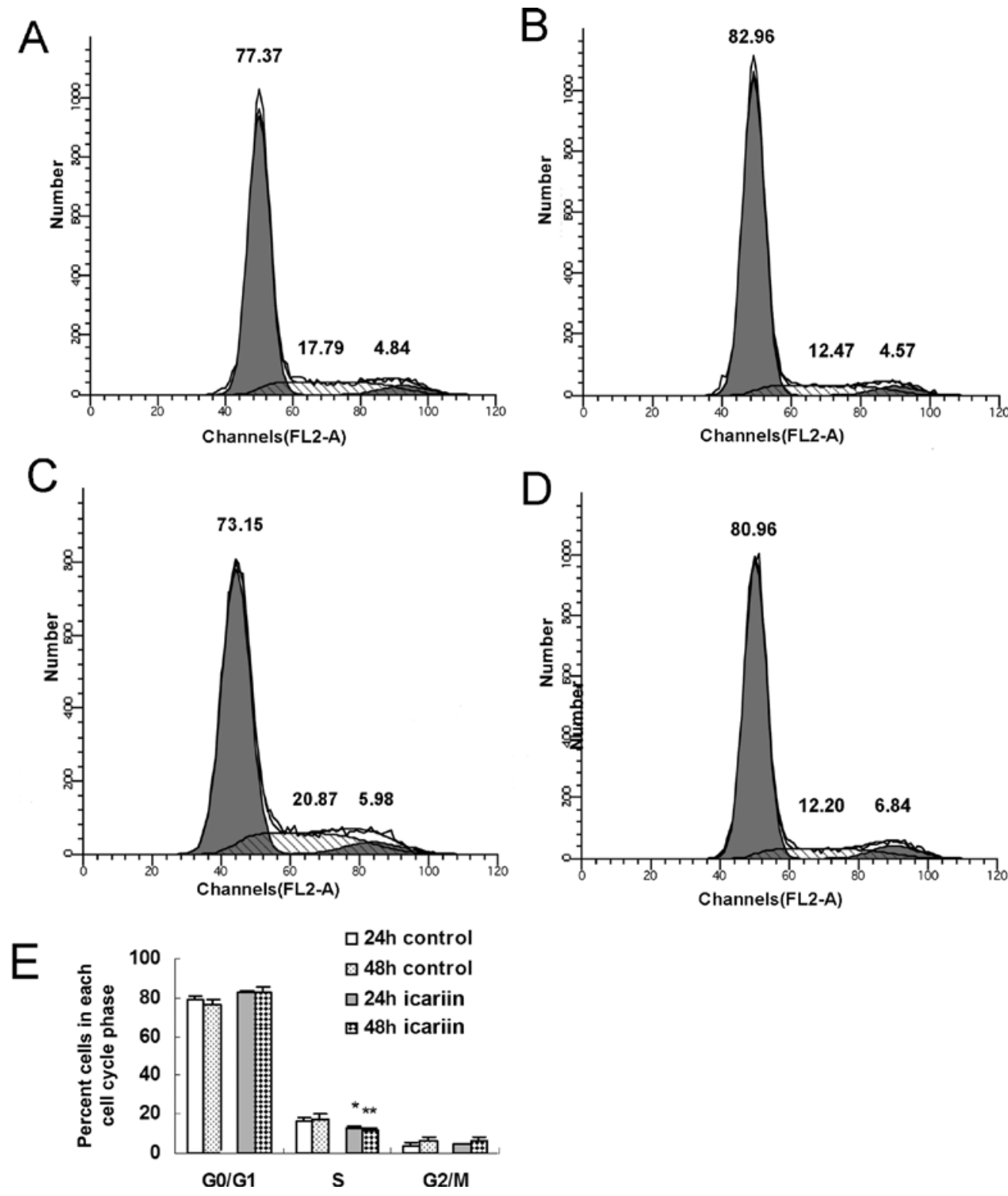

Figure 3. Effect of icariin on the cell cycle distribution of MLTC-1 cells. Representative flow cytometric analysis plot of the (A) 24-h control, (B) $50 \mu \mathrm{g} / \mathrm{ml}$ icariin for $24 \mathrm{~h},(C) 48-\mathrm{h}$ control and (D) $50 \mu \mathrm{g} / \mathrm{ml}$ icariin for $48 \mathrm{~h}$ treatment groups. Cells were fixed with $70 \%$ ethanol and stained with PI, followed by flow cytometric analysis. (E) Percentage of cells in the indicated phases of the cell cycle after $50 \mu \mathrm{g} / \mathrm{ml}$ icariin-treatment as determined by flow cytometry. The data are expressed as the means $\pm \mathrm{SD}(\mathrm{n}=3) .{ }^{*} \mathrm{P}<0.05$, compared to the 24 -h control group; ${ }^{* *} \mathrm{P}<0.05$, compared to the 48 -h control group.

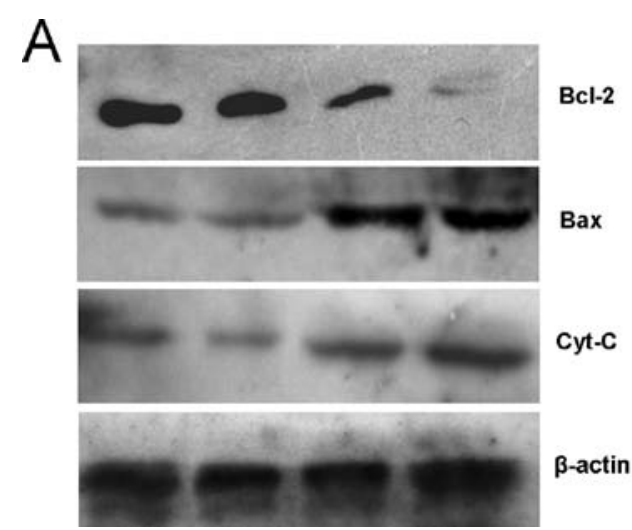

B

Bcl-2

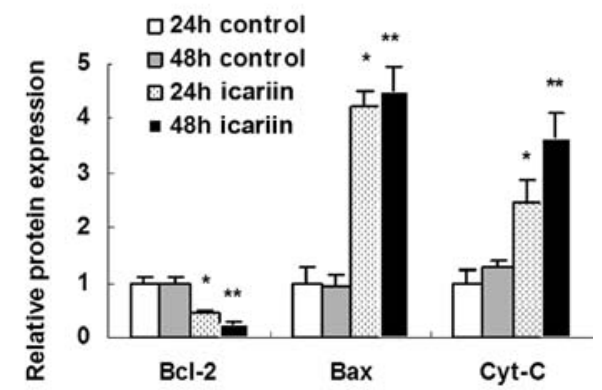

Figure 4. The expression of Bcl-2, Bax and cytochrome c (Cyt-C) in icariin-stimulated MLTC-1 cells. Cells were treated without or with $50 \mu \mathrm{g} / \mathrm{ml}$ icariin for 24 and $48 \mathrm{~h}$, respectively. Bcl-2, Bax and cytochrome c-specific bands were detected by Western blotting. (A) Representative Western blotting of Bcl-2, Bax and cytochrome c. (B) Relative expression of Bcl-2, Bax and cytochrome $\mathrm{c}$ in different groups by normalizing to $\beta$-actin protein level. Protein levels of the control (24 h) group were set as 1 . Values represent the means $\pm \mathrm{SD}(\mathrm{n}=3)$. ${ }^{*} \mathrm{P}<0.01$, compared to the $24 \mathrm{~h}$ control group; ${ }^{* *} \mathrm{P}<0.01$, compared to the $48 \mathrm{~h}$ control group. 


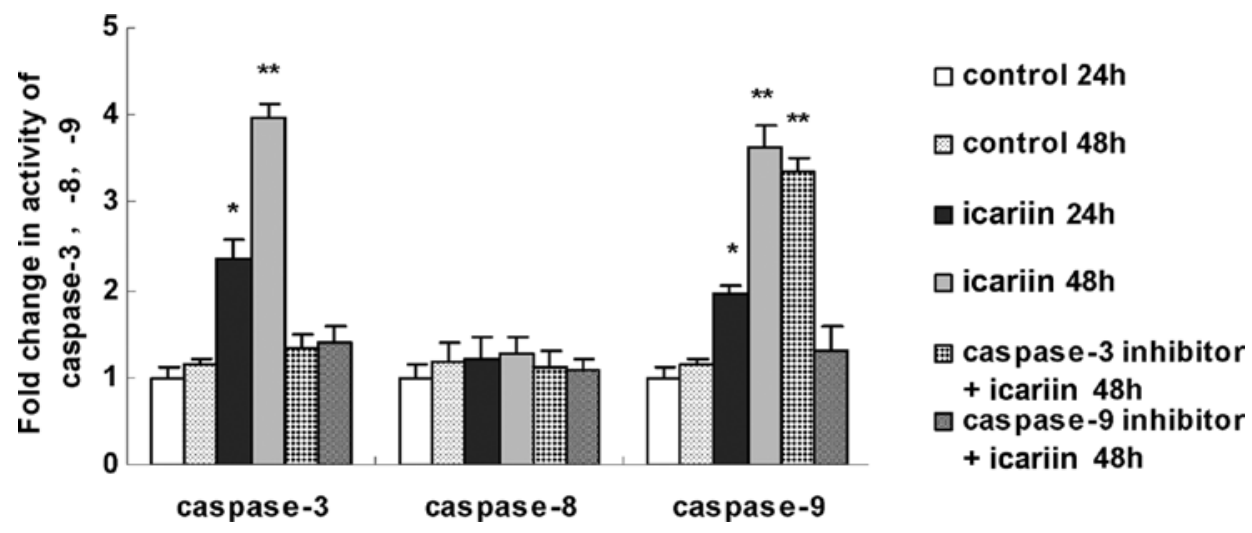

Figure 5. Icariin and caspase activity. (A) Incubation of MLTC-1 with $50 \mu \mathrm{g} / \mathrm{ml}$ icariin for 24 and $48 \mathrm{~h}$ activated caspase-9 and -3 , but not caspase- 8 . Pretreatment of MLTC-1 cells with the caspase-3 inhibitor DEVD-CHO $(25 \mu \mathrm{mol} / 1)$ only inhibited icariin-induced activation of caspase-3, while, pretreatment of caspase-9 inhibitor z-LEHD-fmk $(25 \mu \mathrm{mol} / \mathrm{l})$ inhibited both caspase-3 and -9 activity. Values are means $\pm \mathrm{SD}(\mathrm{n}=3)$. ${ }^{*} \mathrm{P}<0.01$, compared to $24 \mathrm{~h}$ control group; ${ }^{* *} \mathrm{P}<0.01$, compared to $48 \mathrm{~h}$ control group.
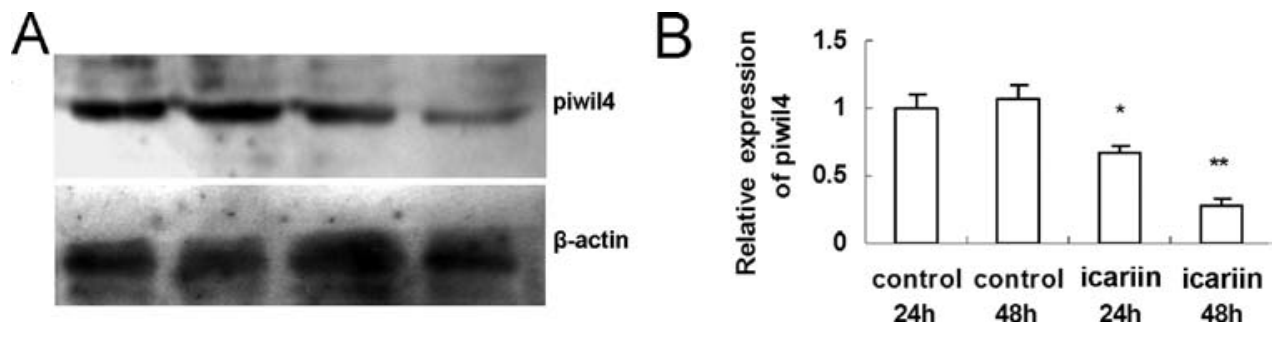

Figure 6. Icariin $(50 \mu \mathrm{g} / \mathrm{ml})$ induces a decrease in piwil4 expression. MLTC-1 cells were treated with $50 \mu \mathrm{g} / \mathrm{ml}$ icariin for 12 and $24 \mathrm{~h}$, then the cells were harvested for Western blot analysis. (A) Representative Western blot analysis for piwil4. (B) Relative expression of piwil4 protein in different groups by normalizing to $\beta$-actin. Piwil4 protein levels at control $(24 \mathrm{~h})$ group were set as 1 . Values represent the means $\pm \mathrm{SD}(\mathrm{n}=3)$. ${ }^{*} \mathrm{P}<0.05$, compared to control $(24 \mathrm{~h})$; ${ }^{* *} \mathrm{P}<0.01$, compared to control $(48 \mathrm{~h})$.

the control group, the percentage of cells in the $\mathrm{S}$ phase was slightly decreased by $50 \mu \mathrm{g} / \mathrm{ml}$ icariin after $24(13.04 \pm 0.89 \%$ vs. $16.68 \pm 1.75 \%, \mathrm{P}<0.05)$ or $48 \mathrm{~h}(11.57 \pm 0.81 \%$ vs. $17.16 \pm 3.26 \%$, $\mathrm{P}<0.05)$ of treatment.

Icariin induces an alteration in Bcl-2, Bax and cytochrome $c$ expression in MLTC-1 cells. Because of the essential role of the Bcl-2 and Bax proteins in the regulation of apoptosis, we examined the effects of icariin on the expression of these regulatory factors. As shown in Fig. 4, $50 \mu \mathrm{g} / \mathrm{ml}$ icariin treatment decreased the expression of the apoptosis inhibitory protein $\mathrm{Bcl}-2$, while it increased the expression of the pro-apoptotic protein Bax. Also, $50 \mu \mathrm{g} / \mathrm{ml}$ icariin treatment, especially at $48 \mathrm{~h}$, induced a significant increase in the release of the mitochondrial activator of apoptosis, cytochrome c.

Icariin induces differential caspases activation related to the apoptosis in MLTC-1 cells. The activity of caspases-3, -8 and -9 in the different groups was detected to investigate whether caspase proteins were activated by icariin in MLTC-1 cells. As shown in Fig. 5A, activation of both caspase-9 and caspase-3, but not of caspase- 8 were observed among icariin treatments at each time-point. Furthermore, compared with icariin alone, pretreatment of MLTC-1 cells with the caspase-3 inhibitor DEVD-CHO $(25 \mu \mathrm{mol} / \mathrm{l})$ inhibited icariin-induced activation of caspase-3, but not of caspase-9, while pretreatment of MLTC-1 with the caspase-9 inhibitor z-LEHD-fmk ( $25 \mu \mathrm{mol} / \mathrm{l})$ inhibited icariin-induced activation of both caspase- 9 and caspase- 3 (both $\mathrm{P}<0.01$ ).

Piwil4 is involved in icariin-induced apoptosis in MLTC-1 cells. The relative expression of piwil4 protein decreased from $68.3 \pm 7.5 \%$ ( $24 \mathrm{~h}$ control) and $73 \pm 7 \%$ ( $48 \mathrm{~h}$ control) to $46 \pm 4 \%$ (24-h treatment of icariin) and $19 \pm 3 \%$ (48-h treatment of icariin), respectively, suggesting that piwil4 may be involved in icariin-induced apoptosis in MLTC-1 cells (Fig. 6).

To further investigate whether piwil4 is related to icariininduced apoptosis, the piwil4-pcDNA ${ }^{\mathrm{TM}}$ 6.2-GW/EmGFP miR (piwil4 miR RNAi) vector was constructed to down-regulate the expression of piwil4 in MLTC-1 cells. Compared to the negative control vector, piwil4 miR RNAi vector reduced piwil4 protein levels to $23 \pm 4.5 \%$ (Fig. 7 ), suggesting that piwil4 miR RNAi vector effectively inhibited piwil4 expression in MLTC-1 cells.

Subsequently, the effect of piwil4 silencing on the $50 \mu \mathrm{g} / \mathrm{ml}$ icariin-induced alterations of cell viability and cell apoptosis were assessed by MTT and flow cytometry analysis, respectively. Compared to parental MLTC-1 cells or MLTC-NC cells, piwil4 silencing exhibited no direct effect on cell viability $(\mathrm{P}>0.05)$. However, on the condition of icariin stimulation, a decrease in cell viability was observed $(\mathrm{P}<0.05)$. Similarly, piwil4 silencing showed no effect on cell apoptosis compared 
A

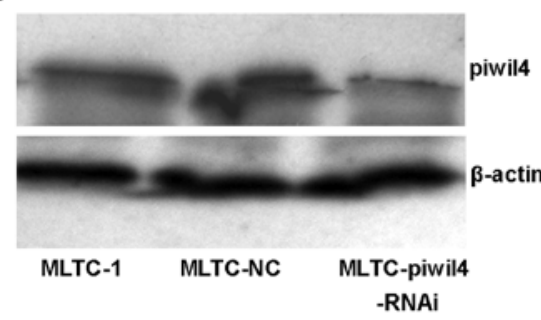

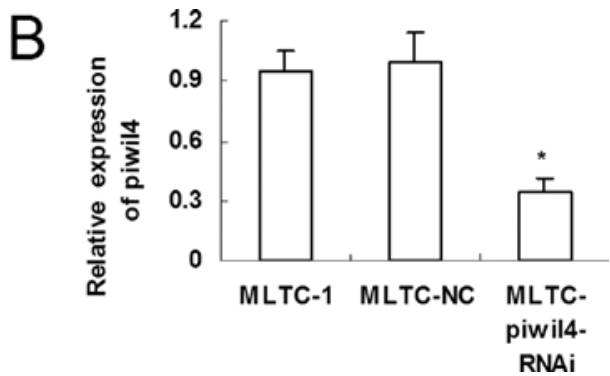

Figure 7. The Piwil4 miR RNAi vector reduces piwil4 protein levels. MLTC-1, parental MLTC-1 cells; MLTC-NC, MLTC-1 cells transduced with negative control miR RNAi vector; MLTC-piwil4-RNAi, MLTC-1 cells transduced with piwil4 miR RNAi vector. (A) Representative Western blotting of piwil4 in MLTC-1 cells of different groups. (B) Relative expression of piwil4 protein in different groups by normalizing to $\beta$-actin protein. Piwil4 protein levels at MLTC-NC control group were set as 1 . Values represent the means $\pm \mathrm{SD}(\mathrm{n}=3) .{ }^{*} \mathrm{P}<0.01$, compared to MLTC-NC group or MLTC-1 group.

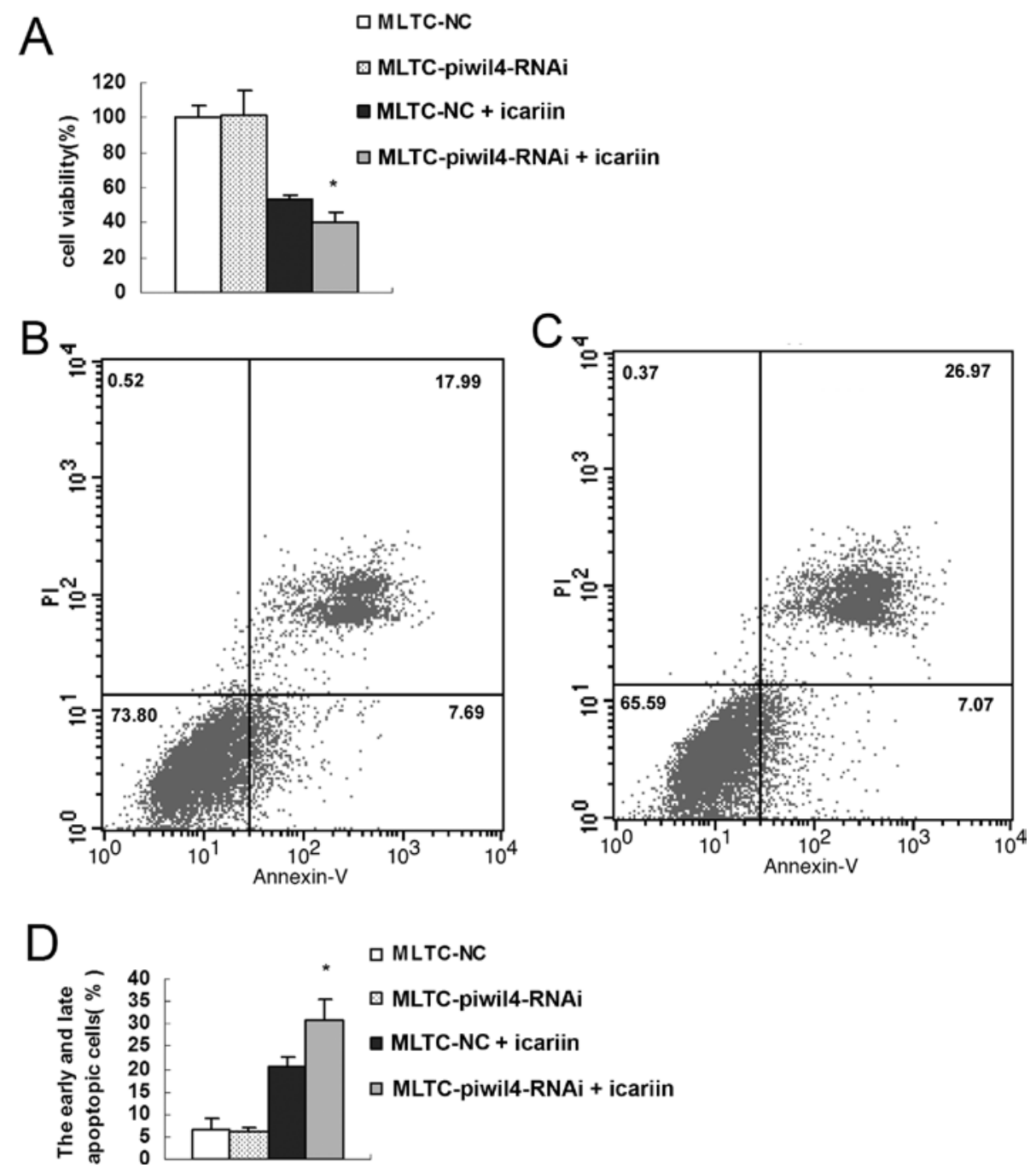

Figure 8. Piwil4 silencing enhances the effect of icariin on MLTC-1 cells.MLTC-NC (transfected with negative miR RNAi vector) and MLTC-1-piwil4-RNAi cells (transfected with piwil4 miR RNAi vector) were treated with $50 \mu \mathrm{g} / \mathrm{ml}$ icariin for $48 \mathrm{~h}$. The MTT and flow cytometry assay were then performed to investigate the cell viability and cell apoptosis, respectively. The results are from three experiments and are presented as means \pm SD. (A) Cell viability was assessed by the MTT assay. (B) and (C) Representative histograms of cell apoptosis analyzed by flow cytometric in icariin-treated MLTC-1-NC and MLTC1-piwil4-RNAi cells. (D) The percentage of cell apoptosis for each treatment group. All the values represent the means $\pm \mathrm{SD}(\mathrm{n}=3$ ). " $\mathrm{P}<0.01$, compared to the icariin-treated MLTC-NC group.

to parental MLTC-1 cells or MLTC-NC cells (data not shown), but enhanced the pro-apoptosis effect induced by icariin (Fig. 8B and C). These results indicate that piwil4 plays a role in the icariin-induced cytotoxicity in MLTC-1 cells.

\section{Discussion}

Several studies have been performed to explore new treatments for Leydig tumors, such as imatinib and cordycepin. Imatinib, 
a tyrosine kinase inhibitor, has activity in gastrointestinal stromal tumors and in a variety of other malignant tumors $(18,19)$. Studies in vitro and in a mouse model have suggested that imatinib may also be active in malignant Leydig cell tumors (20). Cordycepin a constituent from the mycelia of Cordyceps sinensis (CS), is considered an active component with antitumor effects in mouse melanoma and lung carcinoma cells and in human oral cancer cells $(21,22)$. In addition, Jen et al have demonstrated that cordycepin exhibited an antitumor effect in Leydig cell tumors (23).

In this study, we showed that icariin could inhibit the growth of MLTC-1 Leydig tumor cells in vitro. A cell proliferation assay indicated that icariin in a concentration range from 25 to $100 \mu \mathrm{g} / \mathrm{ml}$ had time- and dose-dependent growth inhibitory effects on MLTC-1 cells. The decrease in cell proliferation may be due to an increase in cell apoptosis. In line with this expectation, compared to controls, the percentage of early- and late-apoptotic cells increased to $17.1 \pm 1.5 \%$ and $24.7 \pm 1.6 \%$ by exposure to $50 \mu \mathrm{g} / \mathrm{ml}$ icariin for 24 and $48 \mathrm{~h}$, respectively.

Previous studies have shown an association between cell progression and cancer, and targeting the cell cycle has become an appreciated strategy for tumor treatment $(24,25)$. The cell cycle profile was analyzed in MLTC-1 cells with icariin treatment. The percentage of cells in the $\mathrm{S}$ phase was slightly decreased with $50 \mu \mathrm{g} / \mathrm{ml}$ icariin stimulation for 24 or $48 \mathrm{~h}$, while alterations of the $\mathrm{G}_{0} / \mathrm{G}_{1}$ and $\mathrm{G}_{2} / \mathrm{M}$ cell populations showed no significant differences between the icariin-treated and the control groups. These results demonstrate that icariin causes an alteration in cell cycle progression of MLTC-1 cells. Collectively considering the results from cell apoptosis and cell cycle assays, it was speculated that the inhibition of tumor cell proliferation by icariin was mainly due to an increase in cell apoptosis.

The proteins of the Bcl-2 family, including Bcl-2 and Bax, are key regulators of apoptosis and may act as balancing factors for the cell apoptotic program (26). Bcl-2 related proteins are primarily localized in the outer mitochondrial, nuclear membranes and the endoplasmic reticulum (27). Bcl-2 may function as a protective factor against apoptosis triggered by cytochrome c release from the mitochondria. Bax, a pro-apoptotic protein, is located in the cytosol or loosely attached to membranes. In response to apoptotic stimulus, Bax translocates form the cytosol to the mitochondria, resulting in cytochrome c release and caspases activation $(28,29)$. The Bcl-2 and Bax proteins are sensitive to apoptotic agents, and the ratio of Bcl-2 and Bax is considered to be a good predictive marker for cell will survival or death (30). Here, results of Western blotting indicated that icariin lowered the Bcl-2/ Bax protein expression ratio, implying that the antitumor effects of icariin are elicited through regulation of the expression of the anti-apoptotic protein Bcl-2 and the pro-apoptotic protein Bax. In addition, accompanying the Bax expression increase, cytochrome c was elevated by icariin stimulation, which further confirms the role of $\mathrm{Bcl}-2 / \mathrm{Bax}$ expression in the icariin-induced MLTC-1 cell apoptosis.

Caspases, the important members of the apoptotic machinery, are a large family of proteases, including the upstream initiators (caspase-2, -8, -9, -10, -12) and the downstream effectors (caspase-3, -6,-7) (28). Among these caspases, caspase- 8 is activated in death receptor-mediated apoptosis, while caspase-9, as the upstream caspase in the cytochrome c pathway for apoptosis, is triggered by the release of cytochrome $\mathrm{c}$ from mitochondria (31).

In order to examine the important roles of caspase- 8 and -9 in apoptosis as described above, we next evaluated whether caspase- $8,-9$ as well as the downstream effector, caspase- 3 are involved in the apoptotic effects of icariin. It is evident that icariin treatment resulted in activation of caspase- 9 and -3 , other than caspase- 8 . To further confirm the change of caspase- 9 and -3 in the icariin-treated MLTC- 1 cells, the caspase -9 or -3 inhibitor was added to the media. The results demonstrate that the caspase-3 inhibitor only inhibited icariininduced activation of caspase-3, while the caspase- 9 inhibitor inhibited both caspase- 3 and -9 activity, which indicated that the effector caspase- 3 is triggered by the upstream molecule, caspase-9. These results suggest that icariin can induce apoptosis by activating caspase-9, and the downstream effector, caspase-3.

Piwil4 belongs to the Ago/Piwi family, which is composed of two conserved domains, PAZ and PIWI. The Ago/PIWI proteins have been shown to interact with the ribonuclease (RNase) III enzyme Dicer that catalyzes the maturation of miRNA and siRNA. Within the family, four members of the PIWI-like family, PIWIL1, PIWIL2, PIWIL3 and PIWIL4, have been identified in humans in previous reports, while in the mouse, there are only three Piwi subfamily genes, piwill, piwll2 and piwil4 (32-35). In regards to piwil4 and its tissue distribution, research has mainly focused on its role in spermatogensis (36-38).

We find that piwil4 is expressed in MLTC-1 cells, and interestingly, MLTC-1 cell apoptosis induced by icariin is related to piwil4. Western blotting results illustrate that the relative expression of piwil4 protein was decreased by treatment with $50 \mu \mathrm{g} / \mathrm{ml}$ icariin in a time-dependent manner. To examine whether piwil4 is involved in icariin-induced apoptosis, we used miR RNAi vector to down-regulate the expression of piwil4 in MLTC-1 cells. MTT and flow cytometry results demonstrate that piwil4 silencing enlarged the effect of icariin on cell viability and cell apoptosis, which indicated that piwil4 may be an anti-apoptotic factor, while icariin could exert its antitumor activity by down-regulating piwil4 expression.

In summary, we have shown that icariin has pro-apoptotic activity in MLTC-1 cells by regulating the expression of Bcl-2/ Bax, the release of cytochrome $\mathrm{c}$ and the activity of caspase- 9 and -3. Additionally, piwil4, an important regulator of spermatogenesis, is involved in the icariin-induced cell apoptosis. In reference to its antitumor activity, icariin may be a therapeutic candidate on testicular Leydig cell tumors.

\section{Acknowledgements}

This study was supported by the National Nature Science Foundation of China (30772346; 30300422; 30901062) and the Educational Commission of Chongqing (KJ070320), China.

\section{References}

1. Fowler KA, Gill K, Kirma N, Dillehay DL and Tekmal RR: Overexpression of aromatase leads to development of testicular Leydig cell tumors: an in vivo model for hormone-mediated testicular cancer. Am J Pathol 156: 347-353, 2000. 
2. Petkovic V, Salemi S, Vassella E, Karamitopoulou-Diamantis E, Meinhardt UJ, Fluck CE and Mullis PE: Leydig-cell tumour in children: variable clinical presentation, diagnostic features, follow-up and genetic analysis of four cases. Horm Res 67: 89-95, 2007.

3. Al-Agha OM and Axiotis CA: An in-depth look at Leydig cell tumor of the testis. Arch Pathol Lab Med 131: 311-317, 2007.

4. Quintana S, Venara M, Rey R, Di Clemente N and Chemes HE: Origin and evolution of somatic cell testicular tumours in transgenic mice. J Pathol 221: 443-451, 2010.

5. Giannarini G, Mogorovich A, Menchini FF, Morelli G,De Maria M, Manassero F, Loggini B, Pingitore R, Cavazzana A and Selli C: Long-term follow-up after elective testis sparing surgery for Leydig cell tumors: a single center experience. J Urol 178: 872-876, 2007.

6. Chandak P, Shah A, Taghizadeh A, Tiptaft R and Dasgupta P: Testis-sparing surgery for benign and malignant testicular tumours. Int J Clin Pract 57: 912-913, 2003.

7. Carmignani L, Colombo R, Gadda F, Galasso G, Lania A, Palou J, Algaba F, Villavicencio H, Colpi GM, Decobelli O, Salvioni R, Pizzocaro G, Rigatti $P$ and Rocco F: Conservative surgical therapy for Leydig cell tumor. J Urol 178: 507-511, 2007.

8. Huyghe E, Nohra J, Vezzozi D, Daudin M, Bennet A, Caron P, Thonneau P and Plante P: Fertility before and after treatment of patients with Leydig cell tumour. Prog Urol 17: 841-845, 2007 (In French).

9. Giannarini G, Mogorovich A, Bardelli I, Manassero F and Selli C: Testis-sparing surgery for benign and malignant tumors: a critical analysis of the literature. Indian J Urol 24: 467-474, 2008.

10. Bertram KA, Bratloff B, Hodges GF and Davidson H: Treatment of malignant Leydig cell tumor. Cancer 68: 2324-2329, 1991.

11. Carmignani L, Salvioni R, Gadda F, Colecchia M, Gazzano G, Torelli T, Rocco F, Colpi GM and Pizzocaro G: Long-term follow-up and clinical characteristics of testicular Leydig cell tumor: experience with 24 cases. J Urol 176: 2040-2043, 2006.

12. Chung BH, Kim JD, Kim CK, Kim JH, Won MH, Lee HS Dong MS, Ha KS, Kwon YG and Kim YM: Icariin stimulates angiogenesis by activating the MEK/ERK- and PI3K/Akt/eNOSdependent signal pathways in human endothelial cells. Biochem Biophys Res Commun 376: 404-408, 2008.

13. Hsieh TP, Sheu SY, Sun JS, Chen MH and Liu MH: Icariin isolated from epimedium pubescens regulates osteoblasts anabolism through BMP-2, SMAD4, and Cbfa1 expression. Phytomedicine 17: 414-423, 2010.

14. Nian H, Ma MH, Nian SS and Xu LL: Antiosteoporotic activity of icariin in ovariectomized rats. Phytomedicine 16: 320-326, 2009.

15. Wu H, Lien EJ and Lien LL: Chemical and pharmacological investigations of epimedium species: a survey. Prog Drug Res 60: $1-57,2003$

16. Huang X, Zhu D and Lou Y: A novel anticancer agent, icaritin, induced cell growth inhibition, G1 arrest and mitochondrial transmembrane potential drop in human prostate carcinoma PC-3 cells. Eur J Pharmacol 564: 26-36, 2007.

17. Yang JX, Fichtner I, Becker M, Lemm M and Wang XM: Antiproliferative efficacy of icariin on HepG2 hepatoma and its possible mechanism of action. Am J Chin Med 37: 1153-1165, 2009.

18. Joensuu H, Roberts PJ, Sarlomo-Rikala M, Andersson LC, Tervahartiala $\mathrm{P}$, Tuveson D, Silberman S, Capdeville R, Dimitrijevic S, Druker B and Demetri GD: Effect of the tyrosine kinase inhibitor STI571 in a patient with a metastatic gastrointestinal stromal tumor. N Engl J Med 344: 1052-1056, 2001.

19. Capdeville R, Buchdunger E, Zimmermann J and Matter A Glivec (STI571, imatinib), a rationally developed, targeted anticancer drug. Nat Rev Drug Discov 1: 493-502, 2002.

20. Basciani S, Brama M, Mariani S, De Luca G, Arizzi M, Vesci L, Pisano C, Dolci S, Spera G and Gnessi L: Imatinib mesylate inhibits Leydig cell tumor growth: evidence for in vitro and in vivo activity. Cancer Res 65: 1897-1903, 2005.
21. Nakamura K, Yoshikawa N, Yamaguchi Y, Kagota S, Shinozuka K and Kunitomo M: Antitumor effect of cordycepin (3'-deoxyadenosine) on mouse melanoma and lung carcinoma cells involves adenosine A3 receptor stimulation. Anticancer Res 26 43-47, 2006.

22. Wu WC, Hsiao JR, Lian YY, Lin CY and Huang BM: The apoptotic effect of cordycepin on human OEC-M1 oral cancer cell line. Cancer Chemother Pharmacol 60: 103-111, 2007.

23. Jen CY, Lin CY, Leu SF and Huang BM: Cordycepin induced MA-10 mouse Leydig tumor cell apoptosis through caspase-9 pathway. Evid Based Complement Alternat Med 2011: 984537 , 2011.

24. Schwartz GK and Shah MA: Targeting the cell cycle: a new approach to cancer therapy. J Clin Oncol 23: 9408-9421, 2005.

25. Dickson MA and Schwartz GK: Development of cell-cycle inhibitors for cancer therapy. Curr Oncol 16: 36-43, 2009.

26. Adams JM and Cory S: The Bcl-2 protein family: arbiters of cell survival. Science 281: 1322-1326, 1998.

27. Gotow T, Shibata M, Kanamori S, Tokuno O, Ohsawa Y, Sato N, Isahara K, Yayoi Y, Watanabe T, Leterrier JF, Linden M, Kominami E and Uchiyama Y: Selective localization of Bcl-2 to the inner mitochondrial and smooth endoplasmic reticulum membranes in mammalian cells. Cell Death Differ 7: 666-674, 2000.

28. Nicholson DW: Caspase structure, proteolytic substrates, and function during apoptotic cell death. Cell Death Differ 6: 1028-1042, 1999.

29. Fan TJ, Han LH, Cong RS and Liang J: Caspase family proteases and apoptosis. Acta Biochim Biophys Sin 37: 719-727, 2005.

30. Raisova M, Hossini AM, Eberle J, Riebeling C, Wieder T, Sturm I, Daniel PT, Orfanos CE and Geilen CC: The Bax/Bcl-2 ratio determines the susceptibility of human melanoma cells to CD95/ Fas-mediated apoptosis. J Invest Dermatol 117: 333-340, 2001.

31. Krajewski S, Krajewska M, Ellerby LM, Welsh K, Xie Z, Deveraux QL, Salvesen GS, Bredesen DE, Rosenthal RE, Fiskum G and Reed JC: Release of caspase-9 from mitochondria during neuronal apoptosis and cerebral ischemia. Proc Natl Acad Sci USA 96: 5752-5757, 1999.

32. Tahbaz N, Kolb FA, Zhang H, Jaronczyk K, Filipowicz W and Hobman TC: Characterization of the interactions between mammalian PAZ PIWI domain proteins and Dicer. EMBO Rep 5: 189-194, 2004.

33. Kim VN: Small RNAs just got bigger: Piwi-interacting RNAs (piRNAs) in mammalian testes. Genes Dev 20: 1993-1997, 2006.

34. Kalmykova AI, Klenov MS and Gvozdev VA: Argonaute protein PIWI controls mobilization of retrotransposons in the Drosophila male germline. Nucleic Acids Res 33: 2052-2059, 2005.

35. Zheng K, Xiol J, Reuter M, Eckardt S, Leu NA, McLaughlin KJ, Stark A, Sachidanandam R, Pillai RS and Wang PJ: Mouse MOV10L1 associates with Piwi proteins and is an essential component of the Piwi-interacting RNA (piRNA) pathway. Proc Natl Acad Sci USA 107: 11841-11846, 2010.

36. Carmell MA, Girard A, van de Kant HJ, Bourc'His D, Bestor TH, De Rooij DG and Hannon GJ: MIWI2 is essential for spermatogenesis and repression of transposons in the mouse male germline. Dev Cell 12: 503-514, 2007.

37. Kuramochi-Miyagawa S, Watanabe T, Gotoh K, Totoki Y, Toyoda A, Ikawa M, Asada N, Kojima K, Yamaguchi Y, Ijiri TW, Hata K, Li E, Matsuda Y, Kimura T, Okabe M, Sakaki Y, Sasaki $\mathrm{H}$ and Nakano T: DNA methylation of retrotransposon genes is regulated by Piwi family members MILI and MIWI2 in murine fetal testes. Genes Dev 22: 908-917, 2008.

38. Sugimoto K, Kage H, Aki N, Sano A, Kitagawa H, Nagase T, Yatomi Y, Ohishi N and Takai D: The induction of H3K9 methylation by PIWIL4 at the p16Ink4a. Biochem Biophys Res Commun 359: 497-502, 2007 